SCIENCE AND HUMANITIES JOURNAL.

VOLUME 5, 2005, PP. $24-41$

\title{
PHOSPHORUS CONTENT OF ACID SOIL AND SWEETPOTATO UPTAKE AS AFFECTED BY NITROGEN APPLICATION픈
}

\author{
ANABELLA B. TULIN \\ Professor, PhilRootcrops, Leyte State University, \\ Visca, Baybay, Leyte , Philippines
}

and

\section{SHIGENAO KAWAI}

Professor, Department of Bioscience, Faculty of Agriculture

Iwate University, Morioka, Iwate, Japan

\section{ABSTRACT}

A pot experiment was conducted to study the changes in $P$ content of acid soil as affected by different $N$ levels and sweetpotato uptake. Thirty $\mathrm{cm}$ healthy cuttings of VSP-2 sweetpotato were planted in clay pots filled with $10 \mathrm{~kg}$ soil acid soil. These were applied with $45,90,135$ and $180 \mathrm{~kg} \mathrm{~N} / \mathrm{ha}$ applied at five planting intervals as follows: $T_{1}$ - all at planting; $T_{2}$ - all at one month after planting; $T_{3}-1 / 2$ at planting and $1 / 2$ at one month after planting; $T_{4}-1 / 2$ at planting and $1 / 2$ at two months after planting at $T_{5}-1 / 3$ at planting, $1 / 3$ at one month after planting and $1 / 3$ at two months after planting.

Application of $N$ fertilizers enhanced the availability of added inorganic $P$ in acid soil and the $P$ uptake of sweetpotato. Reduction in $P$ content of acid soil was observed at different stages of plant growth and this was s most evident at harvest. An exponential relationship was established between $P$ removed from acid soil at havest and root yield, emphasizing the important role played by phosphorus aside from $N$ and $K$ in root growth and formation of sweetpotato.

KEY WORDS: P content. Sweetpotato var. Var-2. $N$ levels. Acid soil.

11 Part of the research project entitled, "Management strategies for reclaiming nutrient deficient soils subjected to continuous root crop culfivation" conducted by the senior author funded by PhilRootcrops. 


\section{INTRODUCTION}

With the possible exception of N, P is probably the most important nutrient that has considerable influence on the growth and yield of plants. It is a critical element in natural and agricultural ecosystems throughout the world (Brady and Weil, 1999). It is one of the least available nutrients to plant and the most limiting factor for plant growth in most soil conditions (Hisinger, 2001). A lack of this element is doubly serious since it may prevent other nutrients from being acquired by plants. $P$ influences various physiological and metabolic processes and its deficiency greatly affects the over-all performance of plants. One of the main roles of $P$ in living organisms is in the transfer of energy (Busman, et al., 2002). This macronutrient element is a key component of cellular compounds and is vital to both plant and animal life (Brady and Weil, 1999). Organic compounds that contain $\mathrm{P}$ are used to transfer energy from one reaction to drive another reaction within cells (Busman et al., 2002).

One problem involving $P$ is that most of the phosphorus in the soil is usually rendered unavailable. Furthermore, when soluble sources of this element are supplied to soils in the form of fertilizers, their phosphorus is often "fixed" or rendered unavailable to higher plants, even under the most ideal field conditions (Brady and Weil, 1999). This is because of various factors that influence the availability of inorganic phosphorus in the soil. One of these factors that greatly affect inorganic $\mathrm{P}$ availability in soil is $\mathrm{pH}$.

The amounts of available inorganic $P$ in acid soils are exceptionally low due to fixation by hydrous oxides, precipitation with $\mathrm{Fe}, \mathrm{Al}$ and $\mathrm{Mn}$ ions and fixation by silicate clays. These render inorganic $P$ unavailable to plants. One way to correct this problem is through $\mathrm{P}$ fertilization, which is usually done in combination with $N$ and $K$ fertilizers. $P$ deficiency is probably the second most likely nutritional problem of highly weathered soils and this will greatly affect the growth and development of plants grown in highly weathered soils (Theng, 1980). 
Tropical root and tuber crops vary greatly in their requirements for $P$ (Howeler, 1989). Irish potato is a high yielding crop of short growth duration, which requires high external $P$ concentrations and generally heavy applications of soluble P sources. Taro and sweetpotato are intermediate in their $P$ requirements and generally require relatively high soil $P$ levels by modest applications of $P$ fertilizers. Cassava is highly variable in its $\mathrm{P}$ requirements because of its dependence on an effective association with mycorrhizal fungi.

This research was conducted to study the changes in $P$ content of acid soils as affected by different nitrogen levels and sweet potato uptake.

\section{METHODOLOGY}

Clay pots (size \#12) filled with $10 \mathrm{~kg}$ air-dried acid soil with a soil $\mathrm{pH}$ of 5.0 and a clayey texture were used in the study. These were arranged in the field following a $4 \times 5 \mathrm{CRD}$ factorial replicated 8 times. Healthy cuttings of sweetpotato var. VSP-2 were planted in each pot. Initial chemical characterization of acid soil was done prior to planting.

The different levels of $N$ fertilizer applied were $45,90,135$ and $180 \mathrm{~kg}$ $\mathrm{N} / \mathrm{ha}$. These were applied at different time interval such as $T_{1}-$ all planting; $T_{2}-$ all at one month after planting; $T_{3}-1 / 2$ at planting and $1 / 2$ at one month after planting; $T_{4}-1 / 2$ at planting and $1 / 2$ at two months after planting and $T_{5}-1 / 3$ at planting, $1 / 3$ at one month after planting and $1 / 3$ at two months after planting. A total of 20 treatment combinations were used in the experiment.

$P$ ferilizer was applied to all treatment combinations at the rate of 90 $\mathrm{kg} \mathrm{P}_{2} \mathrm{O}_{5} / \mathrm{ha}$. K was also applied to all pots except the control at $120 \mathrm{~kg}$ $\mathrm{K}_{2} \mathrm{O} / \mathrm{ha}$. Monthly monitoring of $\mathrm{P}$ content of the soil was done starting the first month of planting up to harvest. Determination of amount of available $P$ in the soil was done following Bray P No. 2 method. 


\section{RESULTS AND DISCUSSION}

\section{Soil Characterization}

Results show a reduction in values of these properties at harvest (Table 1).. This is due to nutrient removal by sweetpotato after four months. One exception is the slight increase in the value of exchangeable $\mathrm{K}$ which was caused by addition of $120 \mathrm{~kg} \mathrm{~K}{ }_{2} \mathrm{O} / \mathrm{ha}$ at planting.

Of the different chemical properties determined, exchangeable Ca was removed from the soil in greater amount followed by exchangeable $\mathrm{Mg}$. This result implies an increase in Ca uptake by plants as a result of phosphate fertilization. Jakobsen (1979) reported that fertilizing with phosphate could improve the possibility of $\mathrm{Ca}$.uptake. He found in barley that the effect of $P$ fertilizers was due to continuous uptake of $\mathrm{Ca}$ and not to greater uptake of $P$.

Table 1. Chemical properties of an acid soil used in the study as determined before planting and at harvest.

Soil Chemical Properties

Before Planting * At Harvest*

$\mathrm{pH}$ in $\mathrm{H}_{2} \mathrm{O}$

5.01

4.71

$\mathrm{pH}$ in $\mathrm{KCl}$

3.76

3.91

$\triangle \mathrm{pH}$

$-1.25$

$-0.80$

Total Acidity (me/100g)

1.52

1.17

Exchangeable A1 (me/100g)

0.36

0.79

Organic matter (\%)

4.16

3.68

Exchangeable Bases (me/100g)
a. Exch. K
b. Exch. $\mathrm{Na}$
c. Exch. $\mathrm{Ca}$
d. Exch. Mg

0.65

0.83

0.22

7.93

0.24

11.37

6.59

10.47

Available $\mathrm{P}$ (ppm)

1.05

0.74

Effective CEC (me/100g)

21.69

\footnotetext{
${ }^{*}$ values obtained as average of 20 samples
} 


\section{Changes in P Content of Soil}

High increases in the amount of available $P$ was noted after the first month of planting (Table 2). This was due to added $P$ fertilizers at planting. At three months after planting, most of available P in the soil started to decrease while other treatments still showed increasing values. This could be attributed to the interaction effects between $N$, and $P$ in the soil since in other treatments $N$ fertilizers were applied only at two months after planting. It is probable that increasing amount of $\mathrm{N}$ fertilizers enhances $P$. availability in acid soil.

Simple NPK trials throughout Colombia indicated a significant response to P application in 13 of 24 locations (Howeler and Cadavid, 1983), mainly in the Oxisols of the Eastern Plains (Llamas Orientales) and the Andepts of Cauca Department. These areas not only have low levels of available $P$, generally less than 3 ppm Bray $\|$ - extractable $P$, but they often have a low VAM population as well.

Higher $P$ content was observed at first month of planting, followed by the amount obtained at third month after planting, then by the $\mathrm{P}$ content at harvest which showed the least amount of $P$ (Fig. 1). This general trend holds true at different $\mathrm{N}$ levels. At harvest, all treatments showed a reduction in amounts of available $P$ in the soil as a result of crop uptake.

In relating these findings with the growth and yield curve of VSP-2 sweetpotato, we could see that the rate of increase in vine growth followed a similar pattern as in the level of available $\mathrm{P}$ in the soil (Fig. 2). In vine length for instance, maximum height was obtained on the second month of planting when the amount of $P$ in the soil was also high. 
Table 2. Changes in available $P$ phosphorus content of acid soil at different stages of plant growth.

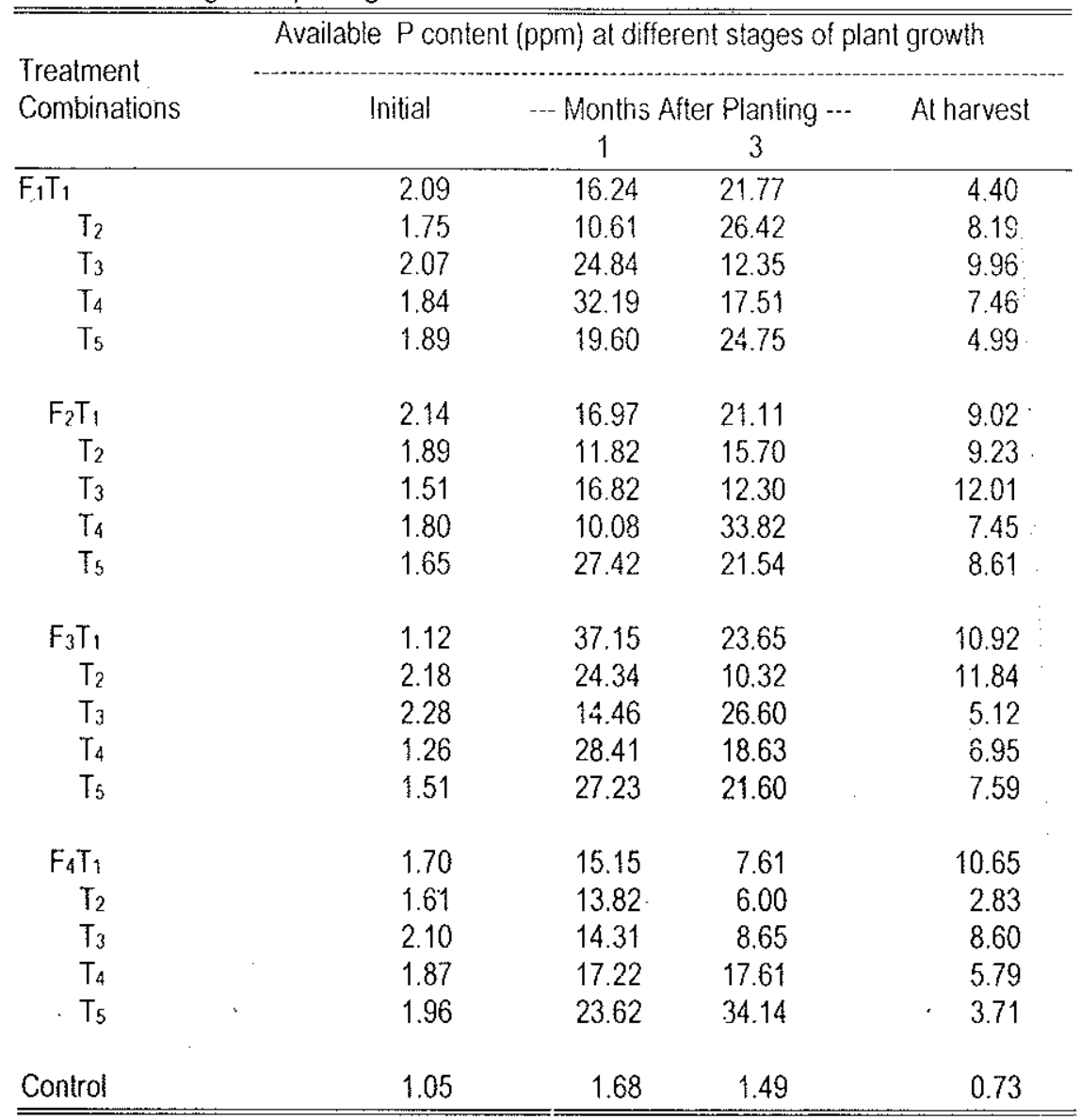

Fertilizer levels:

Timing of Fertilization:

$F_{1}-45 \mathrm{~kg} \mathrm{~N}$ per hectare

T: - all at planting

$\mathrm{F}_{2}-90 \mathrm{~kg} \mathrm{~N}$ per hectare

$T_{2}$ - all at one month alter planting

$\mathrm{F}_{3}-135 \mathrm{~kg} \mathrm{~N}$ per hectare

$\mathrm{F}_{4}-180 \mathrm{~N} \mathrm{~kg}$ per hectare

$T_{3}-1 / 2$ al planting and $1 / 2$ at one month after planting

$T_{4}-1 / 2$ at planting and $1 / 2$ at two months after planting

$T_{5}-1 / 3$ at planting, $1 / 3$ at one month after planting 
Similar studies were conducted on $\mathrm{P}$ absorption during the growth cycle for other tropical root crops such as cassava by Howeler and Cadavid (1983) and yam by Kabeerathumma et al. (1987). Results showed that for cassava, $\mathrm{P}$ and dry matter (DM) accumulation in roots and total plant part start to increase at constant rate after 3 months of planting up to harvest or 12 months of planting. In yam, DM accumulation increased between 3 and 7 months, after which it slowed down; total $P$ accumulation also slowed down after the $5^{\text {th }}$ month but continued in the roots, indicating a marked retranslocation of $\mathrm{P}$ from the tops to the roots during the last 4 months before harvest. These results further explained the changes in the amount of available $P$ in the soil at various growth stages due to crop removal of root crops. Thus, at harvest, low amount of available $P$ in the soil was expected as a result of increased $P$ absorption in roots and other plant parts.

Worth noting in this study is the higher amount of $\mathrm{P}$ after harvest compared to the initial $P$ level. This is due to the addition to the active pool of $P$ through fertilization, which will increase the amount of fixed $P$. Depleting the active pool through crop uptake may cause some of the fixed $P$ to slowly become active $P$ (Busman et al., 2002). The conversion of available $P$ to fixed $P$ could be part of the reason only the efficiency of $P$ fertilizers was low. So most of the P fertilizer applied to the soil will not be utilized fully by the crop in the first season; this would serve as a source of residual $P$ that could supply the $P$ requirement of the crops for the second cropping. Thus allowing some savings on the expenditures of $P$ fertilizers especially in acid soils which normally require higher doses of applied $\mathrm{P}$ fertilizer.

The enhancement of the availability of $P$ in acid soil by $N$ application could be due to microbial action. Autotropic organisms that convert ammonium and reduced sulfur compounds into nitrate and sulfate, 
respectively, can exert an influence on $P$ availability due to the acidity produced (nitric and sulfuric acids) in various oxidation reactions of $P$ in the soil (Follett et al., 1981).

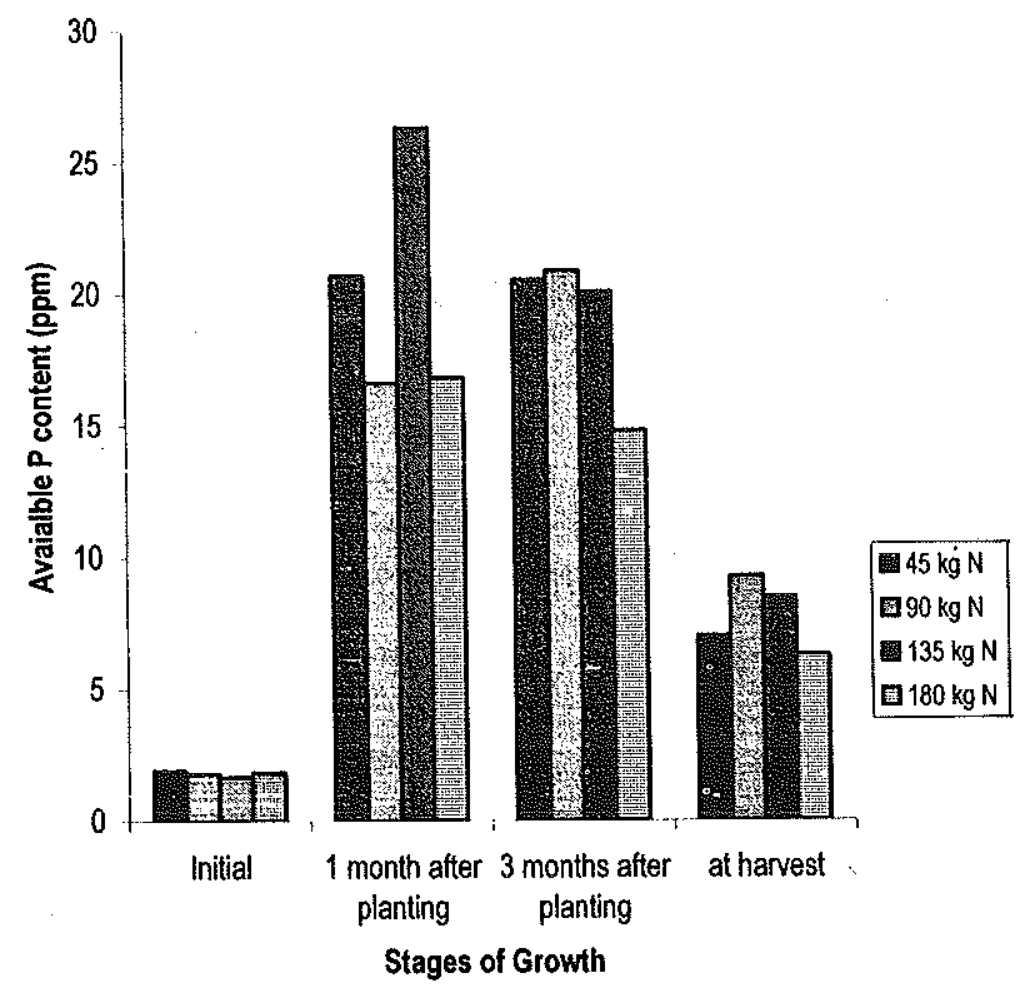

Figure 1. Changes in available $P$ content of an acid soil at different stages of growth as affected by different $\mathrm{N}$ levels. 


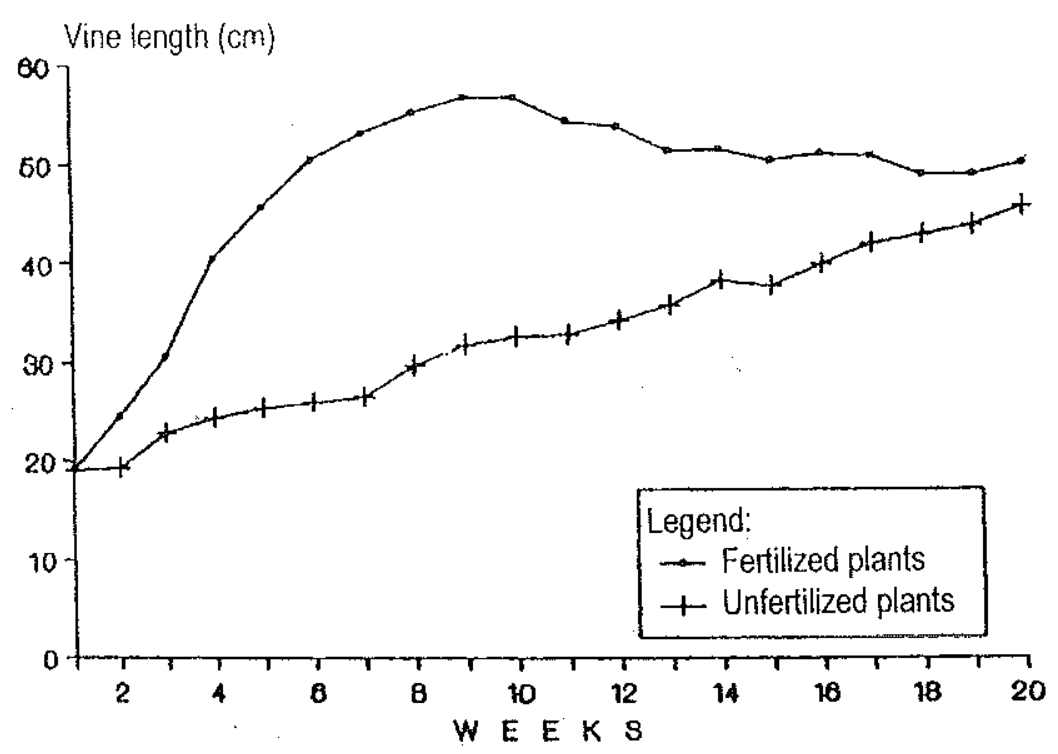

Figure 2. The vine length of fertilized and unfertilized sweetpotato var. VSP-2.

In studying the effects of $N$ level on the $P$ content of soil at different stages of sweetpotato growth, the parabola model $P=B_{0} N^{2}+B_{1} N+e$ was fitted. The predicted $P$ at different stages of sweetpotato growth as affected by $\mathrm{N}$ levels can be based on the equations (Table 3 ). 
From these estimates we could compute the $P$ consumption of plant at different growth stages as affected by $\mathrm{N}$ levels (Figures 3,4 , and 5 ). From the figures we could see that at increasing $\mathrm{N}$ level a sharp increment in $P$ content of soil was observed up to $90 \mathrm{~kg} / \mathrm{ha} \mathrm{N}$. Then this levels off from 90 to $135 \mathrm{~kg} \mathrm{~N} / \mathrm{ha}$. After which an abrupt decrease in $P$ content was evident up to harvest.

\section{Relationship Between P Removed and Root Yield}

The amount of available $P$ removed from acid soil and root yield at harvest show similarity in the behavior of $\mathrm{N}$ and $\mathrm{P}$ in affecting sweetpotato root yield (Table 4). When the results of Table 4 are plotted in a graph, the figure shows that maximum root yield was attained at $90 \mathrm{~kg} \mathrm{~N} / \mathrm{ha}$ which coincide with low amount of available $P$ on the soil equivalent to 14 ppm of Bray P-2 (Figure 8). This finding is important in considering the optimum amount of nutrients like $\mathrm{N}$ and $\mathrm{P}$ for maximum root yield. As in $\mathrm{N}$, a low amount of applied $\mathrm{P}$ is sufficient to attain higher sweetpotato root yield. Since addition of $N$ fertilizers enhances the availability of $P$ in acid soil, this result suggests the minimal application of $P$ fertilizers in combination with $\mathrm{N}$.

Results of simple linear correlation analysis showed a low $r$ value of 0.42 . An exponential model in the form Yield $=B_{0} e^{B 1 P}$ removed $+e$ was tried out to determine the functional relationship between yield and the amount of $P$ removed. Based on this model, the predicted yield is:

$$
\begin{aligned}
& \text { Yield }=384.3676 \mathrm{e}^{0.0487 \text { removed }} \\
& \text { with } F=7.67214
\end{aligned}
$$


Table 3. Estimates of predicted $P$ values at different stages of sweetpotato growth.

\begin{tabular}{lcc}
\hline \hline Stages of SP growth & Predicted P & F-value \\
\hline $\begin{array}{l}\text { First month of } \\
\text { planting }\end{array}$ & $\mathrm{P}=0.00177 \mathrm{~N}^{2}+0.41379 \mathrm{~N}$ & $29.381^{\star *}$ \\
Third month of & $(0.00057) \quad(0.00870)$ & \\
planting & $\mathrm{P}=0.00102 \mathrm{~N}^{2}+0.43732 \mathrm{~N}$ & $59.319^{* *}$ \\
& $(0.00036) \quad(0.05970)$ & \\
At haryest & $\mathrm{P}=0.00078 \mathrm{~N}^{2}+0.17388 \mathrm{~N}$ & $209.270^{* \star}$ \\
& $(0.00008) \quad(0.01288)$ & \\
\hline \hline
\end{tabular}

Values in parenthesis are the standard errors of the estimates.

* Significant at $5 \%$ a

* Significant al $1 \%$ a

Note:

$$
F=\frac{\text { mean square regression }}{\text { mean square residual }}
$$

However, the result was not statistically significant.

The findings of this study further confirmed the degree of $P$ adsorption and removal by root crops in comparison to $N$ and $K$. Generally root crops absorb $N$ and $K$ in greater quantities compared to $P$ in the harvested products. Howeler (1989), in his studies on the role of $P$ in root development of tropical root and tuber crops, reported that $P$ absorption and removal in the harvested products of root and tuber crops is minimal compared to that of $\mathrm{K}$ and $\mathrm{N}$ with the amounts of $\mathrm{K}$ removed ranging from 5 to 10 times as large as that of $N$. Root and tuber crops are among the most efficient producers of carbohydrates (Vries et al., 1967), 
with the energy output per unit area being two to three times higher than that of grain crops (Chandra, 1988). With this potential for high yields, these crops can also be exhaustive of soil nutrients. Of the three major nutrients needed by plants, $\mathrm{N}$ and $\mathrm{K}$ are usually absorbed in greater amounts compared to $P$.

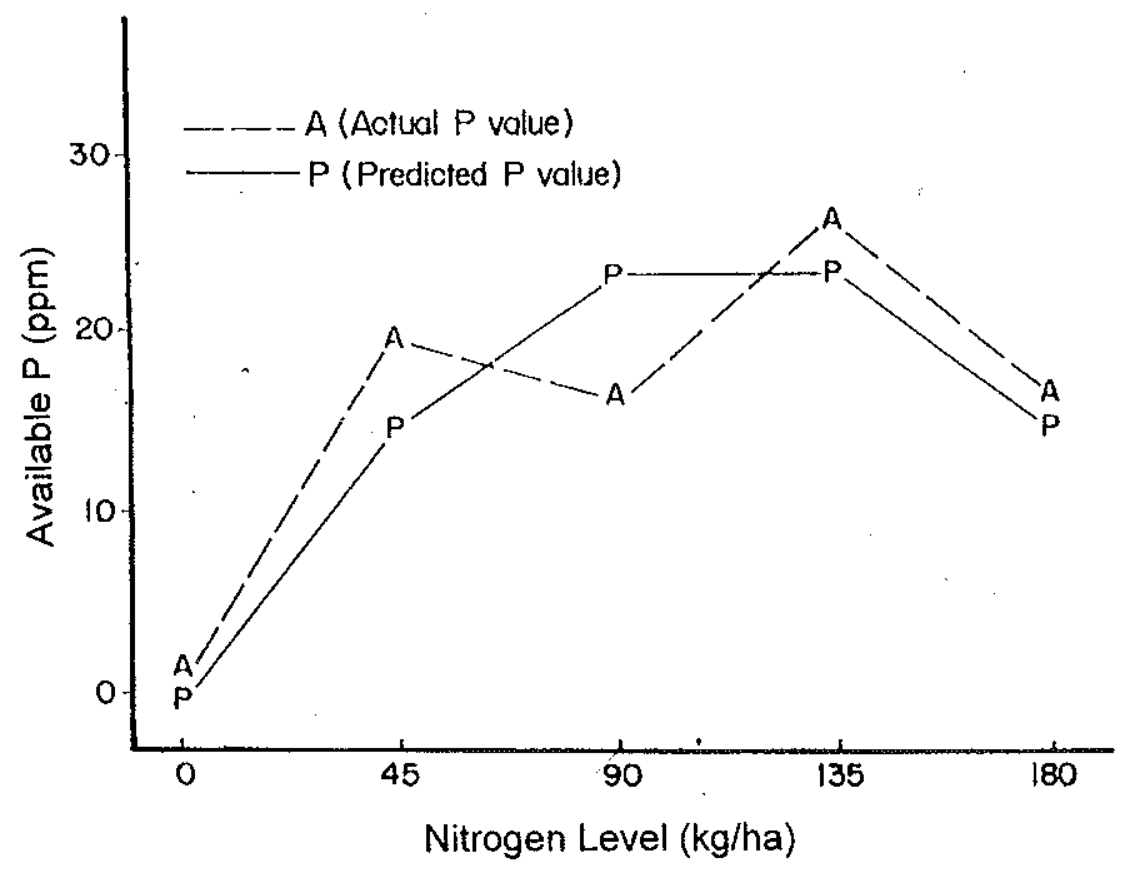

Figure 3. Changes in available $P$ content (ppm) of acid soil as affected by different $\mathrm{N}$ levels one month after planting sweetpotato. 


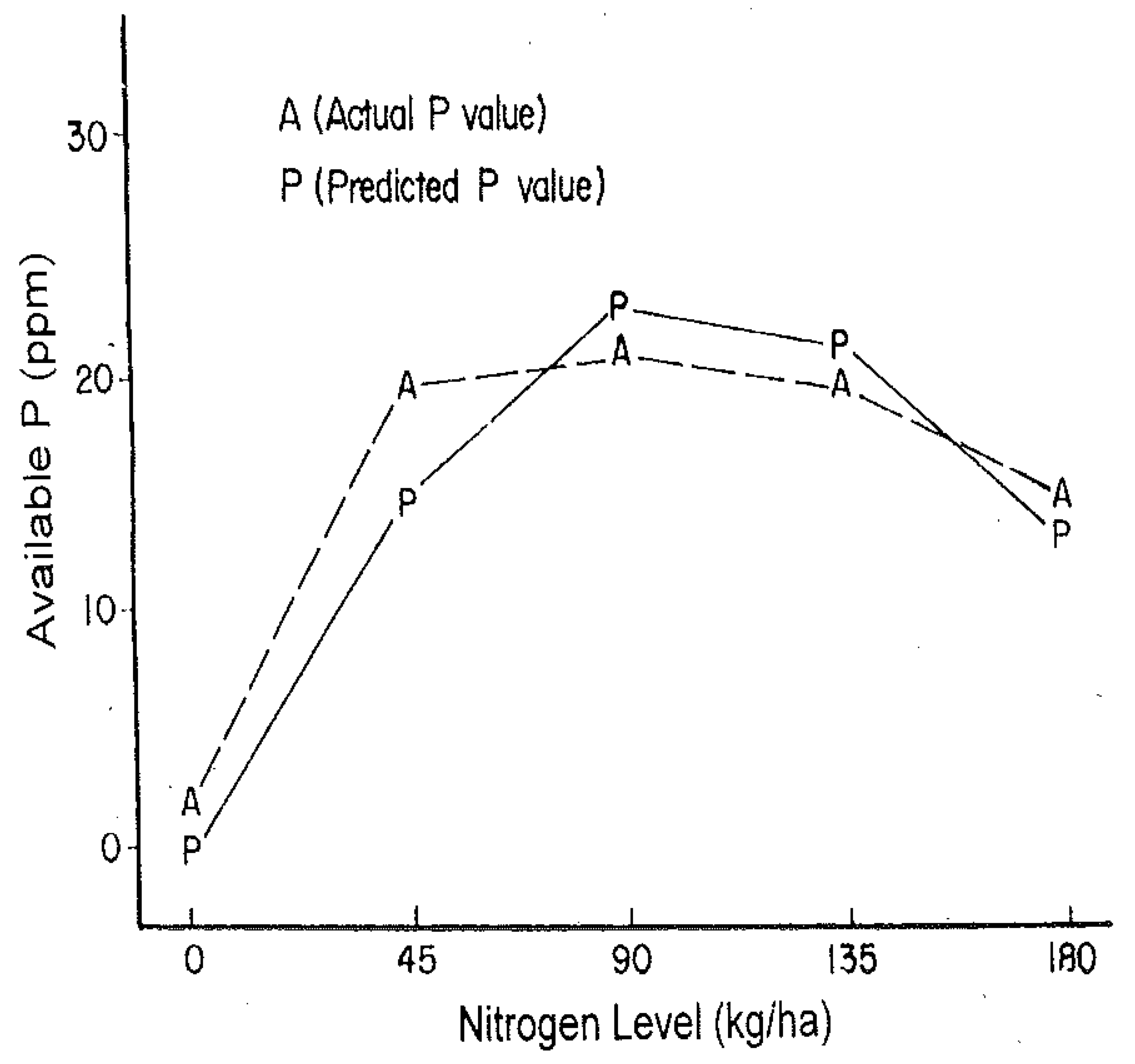

Fig. 4. Changes in available $P$ content (ppm) of acid soil as affected by different $\mathrm{N}$ levels three months after planting sweetpotato. 


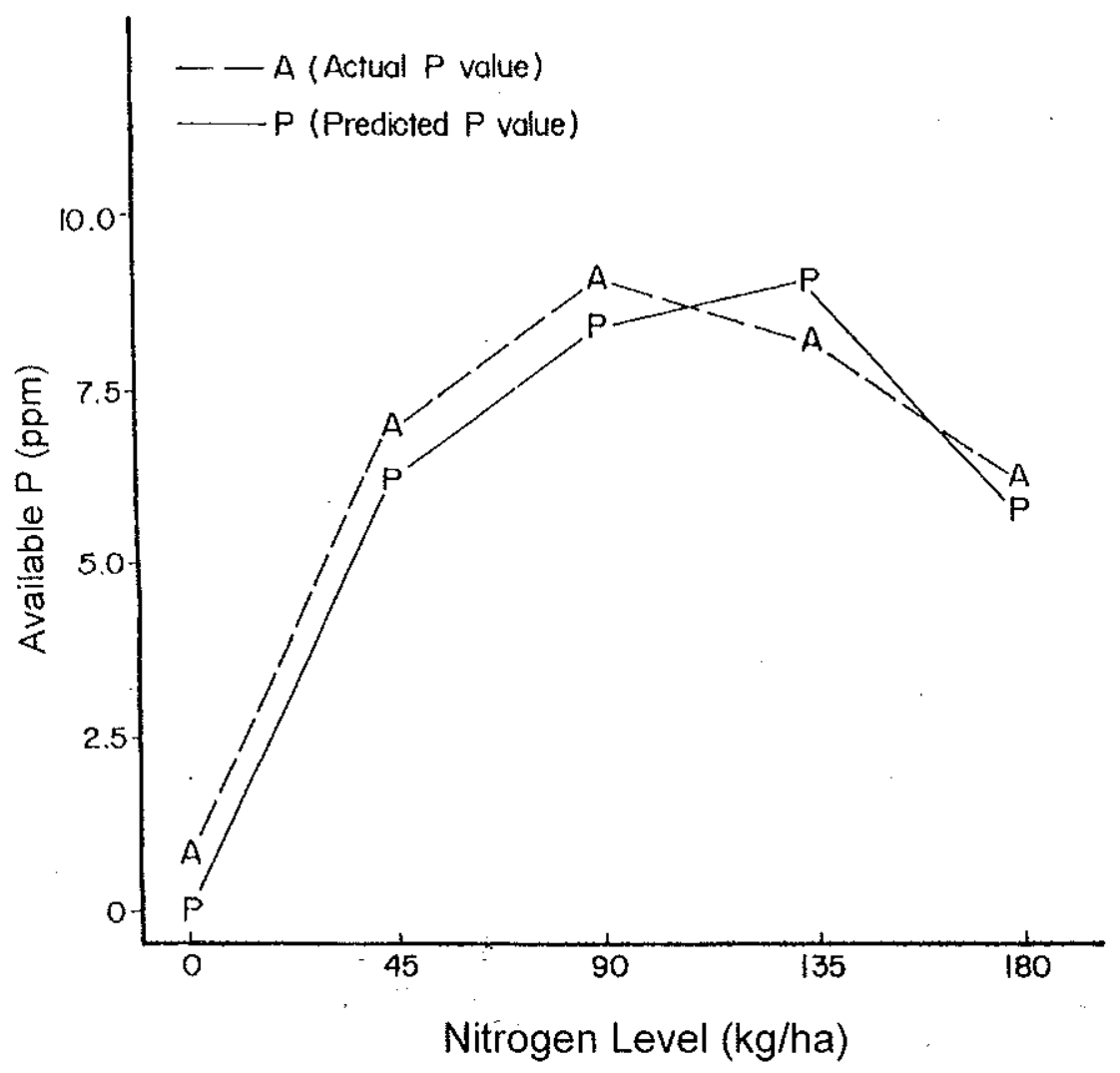

Figure 5. Changes in available $P$ content (ppm) of acid soil as affected by different $\mathrm{N}$ levels and sweetpotato at harvest. 
Table 4. Relationship between available $P$ removed from acid soil and sweetpotato root yield at harvest as affected by rate and timing of $N$ fertilization.

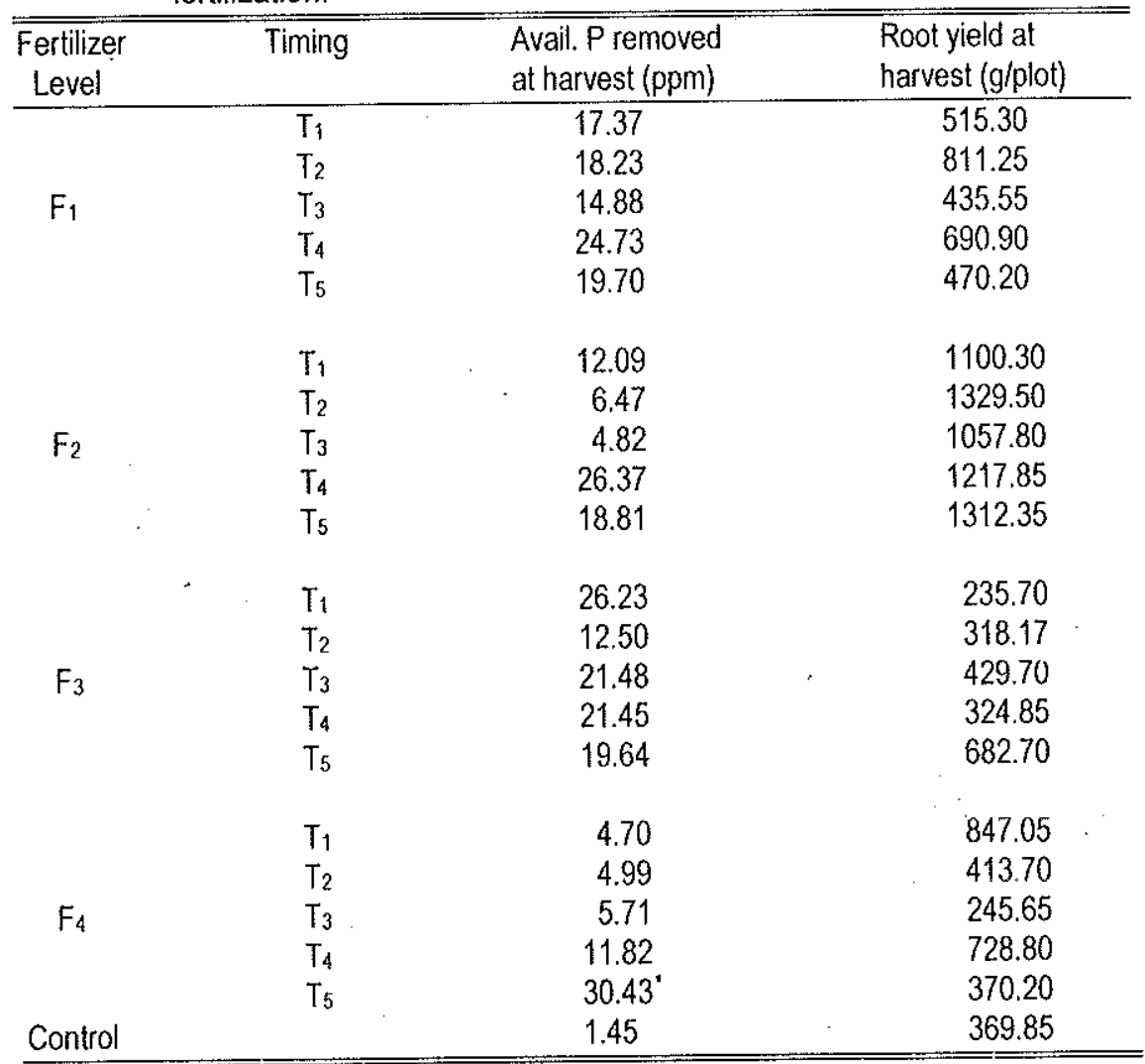

Ferilizer levels:

Timing of Fertilization:

$F_{1}-45 \mathrm{~kg} \mathrm{~N}$ per hectare

$F_{2}-90 \mathrm{~kg} \mathrm{~N}$ per heclare

$\mathrm{F}_{3}-135 \mathrm{~kg} \mathrm{~N}$ per hectare

$\mathrm{F}_{4}-180 \mathrm{~N} \mathrm{~kg}$ per hectare
$T_{1}-$ all at planting

$\mathrm{T}_{2}$ - all at one month alter planting

$T_{3}-1 / 2$ at planting and $1 / 2$ at one month after plariting

$T_{4}-1 / 2$ at planting and $1 / 2$ al two months after planting

$T_{5}-1 / 3$ at planting, $1 / 3$ at one month after planting 


\section{Effects of Timing of N Application on P Content of Soil}

The timing of $\mathrm{N}$ application on the $\mathrm{P}$ content of soil at different growth stages did not show any significant effect. The same result was established in determining the effects of timing of $\mathrm{N}$ application on the growth and yield parameters of sweetpotato (Bautista, 1989). Thus, $N$ fertilizers could be applied to sweetpotato at different time intervals without causing any significant effect on its growth and yield.

\section{CONCLUSION}

Increasing amounts of $\mathrm{N}$ encourages availability of inorganic $\mathrm{P}$ in acid soil and this enhances the amount of available $P$ for sweet potato uptake. The amount of available $P$ in soil declines as a consequence of crop removal and this is very evident at harvest. An exponential relationship could be established between the amount of $P$ removed from the soil and root yield indicating the contribution of $P$ in root development of sweetpotato in acid soil. Increasing $N$ levels also enhanced the availability of $P$ to sweet potato. This emphasizes the important role played by $\mathrm{P}$ aside from $\mathrm{N}$ and $\mathrm{K}$ in root formation and yield of sweetpotato.

\section{LITERATURE CITED}

BAUTISTA, A. T. 1990. Improvement of nitrogen status of leaves of VSP-2 sweetpotato through foliar fertilization. Unpublished Terminal Report. PRCRTC, ViSCA, Baybay, Leyte. 73 pp.

BRADY, N.C. 1974. The Nature and Properties of Soils. $8^{\text {th }}$ Ed. Macmillan Publishing Co. Inc. New York. 639 pp.

BRADY, N.C. and R. R. WEIL. 1999. The Nature and Properties of Soils. $12^{\text {th }}$ Ed. Printice-Hall, Inc. New Jersey. $881 \mathrm{pp}$. 
BUSMAN, L., J. LAMB, G. RANDALL, G. REHM, and M. SCHMITT, 2002. The Nature of Phosphorus in Soils. In Phosphorus in the Agricultural Development. http://www.extension. umn.edu.

CHANDRA, S. 1988. Tropical root and tuber crops and social change in the less developed countries. In Proc. 8th Symp. Inter. Soc. Trop. Root Crops. Oct. 30 - Nov. 5, 1988, Bangkok, Thailand.

FOLLETT, R. H., L.S. MURPHY, R. L. DONAHUE, 1981. Fertilizers and Soil Amendments. Printice-Hall, Inc., Englewood Cliffs, New Jersey, USA. 557pp.

HISINGER, $P$. 2001. Bioavailability of soil inorganic $P$ in rhizosphere as affected by root-induced chemical changes. Plant and Soil. 237:173-195.

HOWELER, R.H. and L.F. CADAVID. 1983. Accumulation and distribution of dry matter and Nutrierts during a 12-month growth cycle of cassava. Field Crops Research 7:123-139.

JAKOBSEN, S.T. 1979. Interaction between phosphate and calcium in nutrient uptake by plant roots. Commun. In soil Sci. and Plant Anal. 10 (1 and 2): 141-152.

KABEERATHUMMMA, S., B. MOHANKUMAR and P.G. NAIR. ' 1987. Nutrient uptake and their utilization by jams, aroids and coleos. Central Tuber Crops Research Institute (CTCRI), Tech. Bull 10. Trivandrum, India $34 \mathrm{pp}$.

THENG, B. K. G. 1980. Soils With Variable Charge. New Zealand Society of Soil Science. Offset Publications, Palmerston North, New Zealand. 


\section{ABOUT THE AUTHOR}

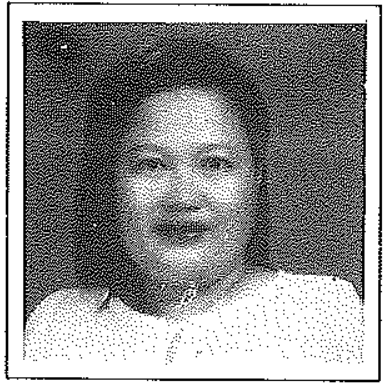

The senior author finished her Bachelor of Science in Agriculture degree major in Soil Science, (Cum laude) from the then Visayas State College of Agriculture (VISCA), now the Leyte State University (LSU), Baybay, Leyte. She earned her Master of Science degree major in Soil Science and minor in Plant Nutrition from the University of the Philippines at Los Baños, Laguna as a PCARRD scholar and obtained her Doctor of Philosophy (Ph.D.) degree in Soil Science major in Soil Chemistry and Mineralogy at Iwate University in Morioka, Iwate, Japan as a Japanese Government Mombusho scholar.

Currently, she is a Professor of Soil Science at the LSU-based Philippine Root Crop Research and Training Center (PhilRootcrops) and an affiliate professor of the Department of Agronomy and Soil Science, Leyte State University. She has published a number of research papers in international refereed journals and has been a recipient of various scholarships, research fellowships and has garnered regional awards as a researcher. 